\title{
Profil Persepsi Siswa terhadap Konsep Materi Himpunan pada Siswa SMP Kelas VII
}

\author{
Petrus Gelang $^{1 \bowtie}$, Kristoforus Djawa Djong ${ }^{2}$ dan Irmina Veronika Uskono ${ }^{3}$ \\ ${ }^{1,2,3}$ Program Studi Pendidikan Matematika Universitas Katolik Widya Mandira
}

\begin{tabular}{|c|c|}
\hline Info Artikel & Abstract \\
\hline $\begin{array}{l}\text { Sejarah Artikel: } \\
\text { Diterima 28 April } 2020 \\
\text { Direvisi 12 Mei } 2020 \\
\text { Disetujui 15 Mei } 2020 \\
\text { Keywords:Profil, Student's } \\
\text { Perception, Concept } \\
\\
\text { Paper type: } \\
\text { Research paper }\end{array}$ & $\begin{array}{l}\text { The purpose of this study was to determine the profile of students' perceptions of the concept of set } \\
\text { material in seventh grade students of junior high school. The type of research used is descriptive } \\
\text { qualitative. The subjects in this study were two seventh grade students of one junior high school in } \\
\text { Kupang City with a high level of ability. Data collection is done by providing problem solving } \\
\text { tasks (TPM), interviews and triangulation. Data analysis techniques used are data reduction, data } \\
\text { presentation and conclusion drawing. In the first indicator, absorption, the results of the study } \\
\text { show that the JW and VO subjects can mention information that is known in the TPM problem and } \\
\text { mention what is asked in the matter of the TPM. In the second indicator, understanding or } \\
\text { understanding, JW and VO subjects can understand how to solve TPM problems and mention the } \\
\text { knowledge used to solve TPM problems. In the third indicator, evaluation or assessment, JW and } \\
\text { VO subjects can solve problems and are able to explain the steps in solving TPM problems. Thus it } \\
\text { can be concluded that both of subjects are able to fulfill all three indicators of perception. }\end{array}$ \\
\hline
\end{tabular}

\begin{abstract}
Abstrak
Tujuan penelitian ini adalah untuk mengetahui profil persepsi siswa terhadap konsep materi himpunan pada siswa kelas VII SMP. Jenis penelitian yang digunakan yaitu deskriptif kualitatif. Subjek dalam penelitian ini yaitu dua orang siswa kelas VII salah satu SMP di Kota Kupang dengan tingkat kemampuan tinggi. Pengumpulan data dilakukan dengan pemberian tugas pemecahan masalah (TPM), wawancara dan triangulasi. Teknik analisis data yang digunakan yaitu reduksi data, penyajian data dan penarikan kesimpulan. Pada indikator pertama yaitu penyerapan, hasil penelitian menunjukkan bahwa subjek JW dan VO dapat menyebutkan informasi yang diketahui dalam soal TPM dan menyebutkan apa saja yang ditanyakan dalam soal TPM. Pada indikator kedua yaitu pengertian atau pemahaman, subjek JW dan VO dapat memahami cara menyelesaikan soal TPM dan menyebutkan pengetahuan yang digunakan untuk menyelesaikan soal TPM. Pada indikator ketiga yaitu evaluasi atau penilaian, subjek JW dan VO dapat menyelesaikan soal dan mampu menjelaskan langkah-langkah penyelesaian soal TPM. Dengan demikian dapat disimpulkan bahwa kedua subjek mampu memenuhi ketiga indikator persepsi.
\end{abstract}

(C) 2020 Universitas Muria Kudus

\begin{tabular}{lc}
\hline Alamat korespondensi: & p-ISSN 2615-4196 \\
Program Studi Pendidikan Matematika & e-ISSN 2615-4072 \\
Fakultas Keguruan dan Ilmu Pendidikan Universitas Muria Kudus & \\
Kampus UMK Gondangmanis, Bae Kudus Gd. L. 1t I PO. BOX 53 Kudus & \\
Tlp (0291) 438229 ex.147 Fax. (0291) 437198 E-mail: & \\
petruegelang5@gmail.com &
\end{tabular}




\section{PENDAHULUAN}

Pendidikan merupakan salah satu faktor penting yang turut mempengaruhi kemajuan dan kesejahteraan dari suatu bangsa dan negara. Oleh karena itu, pemerintah Indonesia melakukan berbagai upaya untuk menghasilkan sumber daya manusia yang berkualitas dan siap berkompetensi dengan berbagai pihak dalam meningkatkan mutu pendidikan. Dalam rangka peningkatan mutu pendidikan, salah satu cara yang dilakukan yaitu meningkatkan pemahaman konsep dan prestasi belajar siswa.

Belajar merupakan proses dari seorang individu sebagai upaya untuk mencapai tujuan dari proses belajar sendiri yaitu untuk membentuk perubahan perilaku yang bersifat menetap. Keberhasilan proses pembelajaran pada bidang studi matematika dapat dilihat dari kemampuan siswa dalam memahami suatu konsep atau materi pada mata pelajaran matematika. Semakin tinggi tingkat keberhasilan yang dicapai siswa, semakin tinggi juga kemampuan yang dimiliki siswa dalam memahami materi tertentu.

Berdasarkan hasil wawancara dengan guru dikatakan bahwa pemahaman pada mata pelajaran matematika masih kurang. Hal ini mengakibatkan prestasi belajar matematika siswa yang menjadi rendah. Sering kali ditemui siswa kurang tertarik mengikuti pelajaran matematika, ada pula siswa yang takut dan bahkan benci pada pelajaran matematika. Anggapan buruk tersebut dapat mengakibatkan motivasi belajar terhadap mata pelajaran matematika menjadi rendah dan menyebabkan anak menjadi kesulitan belajar matematika.

Dalam proses pembelajaran guru tentu melakukan penilaian dan akan lebih baik bila sekaligus menganalisis hasil tes. Masalah tingkat ketuntasan kelas masih kurang dari 75\% (jumlah siswa yang telah kompeten), yang berarti pelajaran yang telah diberikan guru belum diserap dengan baik oleh siswa. Untuk itu perlu dikaji kembali apakah soalnya yang terlalu sulit, atau cara pembelajaran yang kurang baik sehingga siswa kurang memahami materi pembelajarannya.

Kesulitan yang dialami siswa dalam proses pembelajaran matematika pada materi himpunan akan nampak ketika siswa menyelesaikan soal pemecahan masalah materi himpunan tersebut. Pemecahan masalah merupakan bentuk pemikiran yang terarah secara langsung untuk menemukan atau menentukan solusi dari suatu masalah yang lebih spesifik (Ratnasari, 2014). Lebih lanjut, (Chotimah,
2014) menyatakan kemampuan pemecahan masalah matematis adalah kemampuan mengindenfikasi unsur-unsur yang diketahui dan ditanyakan, mampu membuat atau menyusun model matematika, dan mengembangkan strategi pemecahan masalah, mampu menjelaskan dan memeriksa kebenaran dari jawaban yang diperoleh. Dengan motivasi dari guru serta sarana dan prasarana diharapkan dapat membantu siswa dalam melakukan pemecahan masalah sehingga siswa dapat menunjukan persepsi yang baik dalam mata pelajaran matematika.

Persepsi merupakan aspek psikologis bagi manusia dalam merespon berbagai aspek dan gejala di sekitarnya. Menurut Slameto (Tarmiji, 2016) persepsi adalah proses yang menyangkut masuknya pesan atau informasi ke dalam otak manusia. Lebih lanjut, Slameto mengemukakan bahwa prinsip dasar tentang persepsi yang perlu diketahui oleh seorang guru yaitu agar dapat mengetahui siswanya secara lebih baik dan menjadi komunikator yang efektif, persepsi itu relatif bukannya absolute. Menurut Setiadi (2015) persepsi merupakan suatu yang timbul akibat adanya sensasi, di mana pengertian sensasi adalah aktivitas merasakan keadaan emosi yang menggembirakan.

Respon yang diberikan sebagai akibat dari persepsi dapat diambil oleh individu dalam berbagai macam bentuk. Stimulus mana yang akan mendapatkan respon dari individu tergantung pada perhatian individu yang bersangkutan. Berdasarkan hal tersebut, apabila perasaan, kemampuan berfikir, pengalamanpengalaman yang dimiliki individu tidak sama, maka dalam mempersepsi suatu stimulus, hasil persepsi mungkin akan berbeda antara indvidu satu dengan individu lain.

Setiap orang mempunyai kecenderungan dalam melihat benda yang sama dengan cara yang berbeda-beda. Perbedaan tersebut bisa dipengaruhi banyak faktor, diantaranya adalah pengetahuan, pengalaman dan sudut pandangnya. Menurut Toha (Arifin, 2017) persepsi dipengaruhi oleh faktor internal dan faktor eksternal. Faktor internal mencakup perasaan, sikap dan karakteristik individu, prasangka, keinginan atau harapan, perhatian (fokus), proses belajar, keadaan fisik, gangguan kejuwaan, nilai dan kebutuhan juga minat dan motivasi. Faktor eksternal mencakup latar belakang keluarga, informasi yang diperoleh, pengetahuan dan kebutuhan sekitar, intensitas, ukuran, keberlawanan, pengulangan gerak, hal-hal baru dan familiar atau ketidakasingan suatu objek. 
Dalam penelitian ini, indikator persepsi yang digunakan yaitu indikator menurut Bimo Walgito (Akbar, 2015). Terdapat tiga indikator persepsi yang ditetapkan oleh Bimo Walgito antara lain: penyerapan, pengertian atau pemahaman dan penilaian atau evaluasi. Pada indikator penyerapan, rangsang atau objek tersebut diserap oleh panca indra secara sendirisendiri maupun bersama-sama. Dari hasil penyerapan ini, selanjutnya akan diperoleh gambaran, tanggapan atau kesan di dalam otak. Indikator penyerapan yang dimaksud dalam penelitian ini yaitu siswa dapat menentukan informasi apa saja yang ditemukan dalam masalah.

Pada indikator pengertian atau pemahaman, gambaran-gambaran di dalam otak selanjutnya digolong-golongkan (diklasifikasikan), dibandingkan, diinterpretasikan sehingga terbentuk pengertian atau pemahaman. Proses terjadinya pengertian atau pemahaman unik dan cepat. Hal ini juga bergantung pada gambarangambaran lama yang telah dimiliki individu sebelumnya. Indikator pengertian atau pemahaman yang dimaksud dalam penelitian ini yaitu siswa dapat memahami cara menyelesaikaan soal/masalah.

Pada indikator penilaian atau evaluasi individu membandingkan pengertian atau pemahaman yang baru diperoleh dengan kriteria yang dimiliki indivisu secara subjektif. Penilaian individu ini akan berbeda-beda meskipun objeknya sama, sehingga persepsi bersifat individual. Indikator evaluasi atau penilaian yang dimaksud dalam penelitian ini yaitu siswa dapat menyelesaikan soal dan memeriksa kembali penyelesaian. Indikator persepsi tersebut dijabarkan seperti pada Tabel 1 .

Tabel 1. Indikator Persepsi

\begin{tabular}{lll}
\hline No & Indikator & \multicolumn{2}{c}{ Deskriptif } \\
\hline 1 & Penyerapan & $\begin{array}{l}\text { Siswa dapat menentukan } \\
\text { informasi apa saja yang } \\
\text { ditemukan dalam masalah } \\
\text { tesebut. }\end{array}$ \\
\hline 2 & $\begin{array}{l}\text { Pengertian } \\
\text { /pemahaman }\end{array}$ & $\begin{array}{l}\text { Siswa dapat memahami } \\
\text { cara menyelesaikan soal / } \\
\text { masalah. }\end{array}$ \\
\hline 3 & Evaluasi & / Siswa dapat menyelesaikan \\
penilaian & $\begin{array}{l}\text { soal dan memeriksa kembali } \\
\text { penyelesaian }\end{array}$ \\
\hline
\end{tabular}

Berdasarkan uraian tesebut maka tujuan yang ingin dicapai dalam penelitian ini adalah untuk mengetahui profil persepsi siswa terhadap konsep materi himpunan pada siswa kelas VII salah satu SMP di Kota Kupang.

\section{METODE PENELITIAN}

Jenis penelitian yang digunakan yaitu deskriptif kualitatif dengan menggunakan alat ukur berupa soal tugas pemecahan masalah (TPM). Banyaknya soal TPM adalah satu nomor, namun untuk keperluan triangulasi dibuat dua soal yang setara. Subjek dalam penelitian ini adalah 2 orang siswa kelas VII salah satu SMPN di Kota Kupang yang memiliki tingkat kemampuan tinggi.

Dalam penelitian ini, yang menjadi instrumen utama adalah peneliti sendiri yang bertugas mengumpulkan, menganalisis, menginterprestasi data. Sedangkan, yang menjadi instrumen pendukung dalam penelitian ini adalah tugas pemecahan masalah siswa dan pedoman wawancara.

Teknik pengumpulan data yang digunakan dalam penelitian ini adalah tugas pemecahan masalah, wawancara, dan triangulasi. Triangulasi yang digunakan yaitu triangulasi waktu. Teknik analisis data yaitu berupa tahap reduksi data, penyajian data dan penarikan kesimpulan.

\section{HASIL DAN PEMBAHASAN}

Instrumen yang digunakan dalam penelitian ini adalah dua nomor soal tugas pemecahan masalah dengan tingkat kesulitan yang setara. Hal ini dilakukan untuk keperluan triangulasi. Tabel 2 menunjukkan soal TPM yang digunakan.

Tabel 2. Tugas Pemecahan Masalah

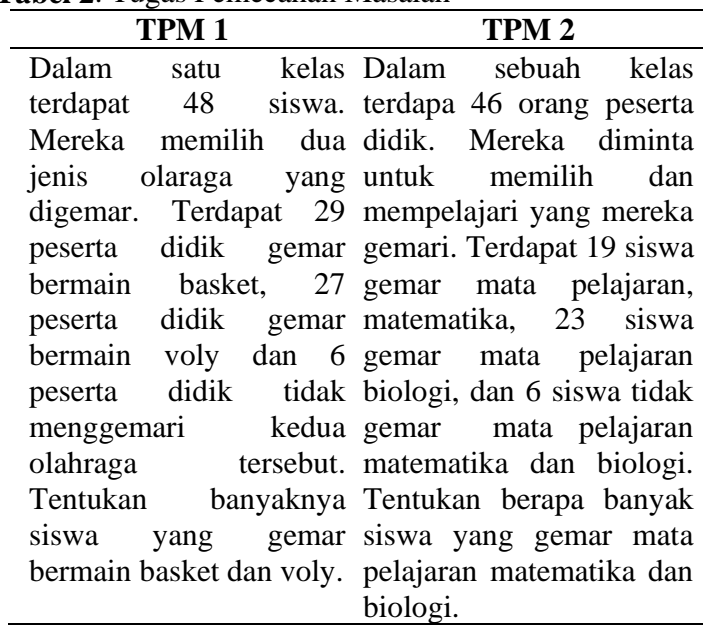

Pemilihan subjek penelitian dilakukan melalui hasil diskusi dengan guru mata pelajaran. Selain hasil diskusi, subjek juga dipilih berdasarkan nilai ulangan harian matematika siswa. Banyaknya siswa yang dipilih untuk menjadi subjek penelitian yaitu 2 siswa. Tabel 3 
menunjukkan nama dari subyek penelitian yang dipilih.

Tabel 3 Subjek penelitian

\begin{tabular}{c|c|c|c}
\hline No & Nama & Nilai & KKM \\
\hline 1 & JW & 97 & Tinggi \\
\hline 2 & VO & 100 & Tinggi \\
\hline
\end{tabular}

A. Paparan Subjek JW Berdasarkan Indikator Penyerapan

1. Deskripsi Hasil TPM I Subjek JW dalam Indikator Penyerapan

Berikut merupakan hasil wawancara subjek JW pada TPM I:

PT : Dapatkah kamu menyebutkan

106 informasi atau hal-hal yang diketahui dari soal tersebut?

JW : Dari soal ini yang diketahui, dalam

106 suatu kelas terdapat 48 siswa. 29 siswa gemar bermain basket, 27 siswa gemar bermain voli, dan 6 siswa tidak gemar bermain basket dan voli.

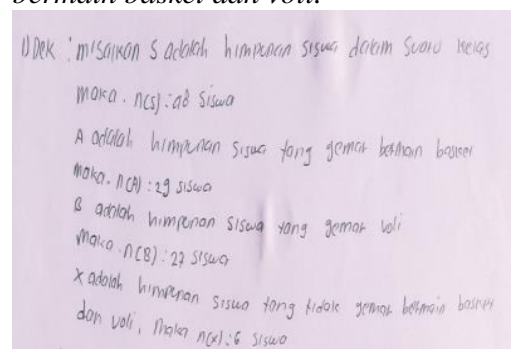

PT : Adik dari soal tersebut, apa sajakah 107 yang ditanyakan?

JW Yang di tanyakan dalam soal ini

107 adalah yang pertama berapa banyak siswa yang gemar bermain basket dan voli

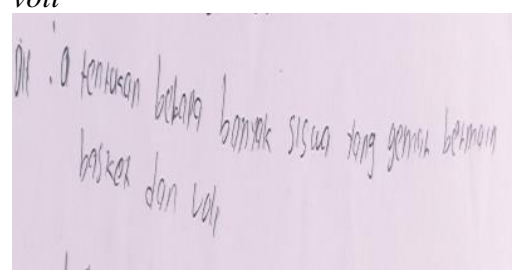

2. Deskripsi Hasil TPM II Subjek JW dalam Indikator Penyerapan

Berikut merupakan hasil wawancara subjek JW pada TPM II:

PT : Dapatkah kamu menyebutkan hal-hal 206 yang diketahui dari masalah tersebut?

JW : Dari soal ini yang diketahui adalah 206 dalam sebuah kelas terdapat 46 siswa. 19 siswa gemar mata pelajaran matematika, 23 siswa gemar mata pelajaran biologi, dan16 siswa tidak gemar mata pelajaran matematika dan biologi

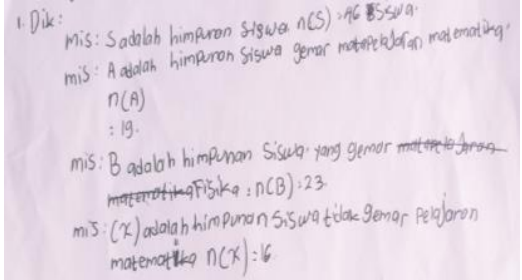

PT

207

JW

207
: Ok baik, dari soal tersebut apa sajakah yang ditanyakan dalam masalah tersebut?

: Dari soal ini yang ditemukan dari masalah tersebut adalah berapa banyak siswa yang gemar mata pelajaran matematika dan biologi.

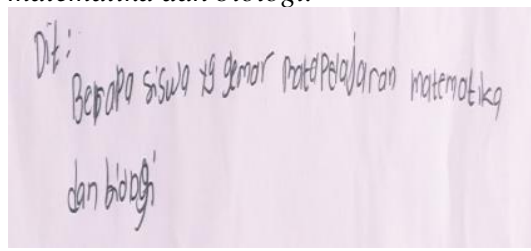

3. Validasi dan Kesimpulan Data Subjek JW

Untuk mengetahui validitas data terhadap konsep dalam pemecahan masalah matematika siswa ditinjau dari persepsi subjek JW dalam indikator penyerapan pada TPM I dengan TPM II maka dilakukan triangulasi waktu untuk mencari kesamaan/kesesuaian data wawancara. Triangulasi yang dimaksud dapat dilihat pada Tabel 4.

Tabel 4. Validasi Data Subjek JW Pada Indikator Penyerapan

\begin{tabular}{llr}
\hline \multicolumn{2}{l}{ Data TPM I } & \multicolumn{2}{l}{ Data TPM II } \\
\hline Subjek mampu & Subjek mampu \\
menyebutkan apa & menyebutkan apa yang \\
yang diketahui dari & diketahui dari soal (JW \\
soal (JW 106) & 206) \\
\hline Subjek mampu & Subjek \\
menyebutkan apa & menyebutkan apa saja \\
saja yang ditanyakan & yang ditanyakan dalam \\
dalam soal tersebut & soal tersebut ( JW 207) \\
(JW 107) & \\
\hline
\end{tabular}

Tabel 4 menunjukkan ada konsistensi subjek JW dalam indikator penyerapan pada TPM I dan TPM II. Oleh karena itu data indikator penyerapan pada TPM I merupakan data yang valid.

B. Paparan Subjek JW Berdasarkan Indikator Pemahaman

1. Deskripsi Hasil TPM I Subjek JW dalam Indikator Pemahaman

Berikut merupakan hasil wawancara subjek JW pada TPM I:

PT : Dari soal tersebut bagaimana cara 109 penyelesaiannya?

JW : Begini pak, (sambil melihat lembar 
109

penyelesaian)

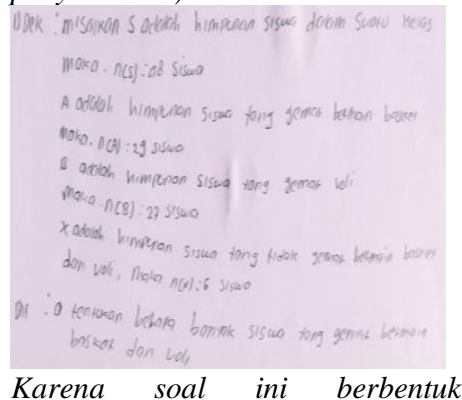

Karena soal ini berbentuk himpunan maka saya menyelesaikannya dengan menggunakan operasi himpunan irisan, untuk mencari siswa yang gemar bermain basket dan voli

PT : Pengetahuan apa sajakah yang

110 kamu gunakan untuk menjawab soal tersebut?

JW : Saya menggunakan operasi

110 himpunan irisan, dengan cara operasi himpunan pada irisan maka rumus yang digunakan adalah

$n(A \cap B)=(n(A)+(B))-(n(S)-(x))$

PT : Kenapa kamu memilih operasi

111 himpunan pada irisan dalam menyelesaikan soal tersebut?

JW : (Sambil melihat hasil

111 pekerjaannya), karena dengan operasi himpunan irisan ini cocok untuk kita gunakan dalam menyelesaikan soal ini.

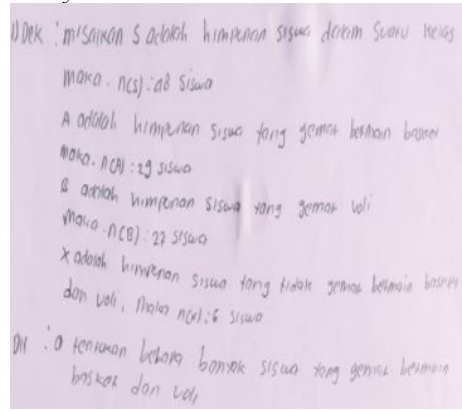

Karena dengan operasi himpunan irisan bisa kita gunakan untuk mencari beberapa banyak siswa yang gemar bermain basket dan voli.

2. Deskripsi Hasil TPM II Subjek JW dalam Indikator Pemahaman

Berikut merupakan hasil wawancara subjek JW pada TPM II:

PT : Dari soal tersebut bagaimana cara

209 penyelesaiannya?

JW : Begini pak, (sambil melihat lembar

209 penyelesaian)

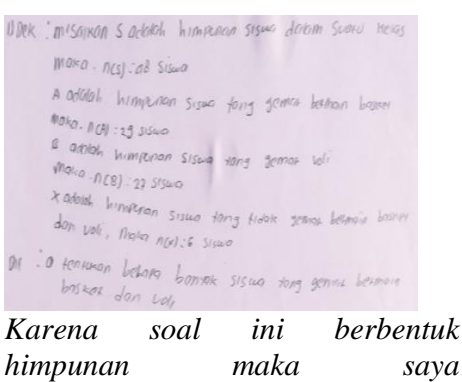
himpunan maka saya menyelesaiakannya dengan menggunakan operasi himpunan irisan, untuk mencari siswa yang gemar bermain basket dan voli

PT : Pengetahuhan apa sajakah yang

210 kamu gunakan untuk menjawab soal tersebut?

JW : Saya menggunakan operasi

210 himpunan irisan, dengan cara operasi himpunan pada irisan maka rumus yang digunakan adalah, $n(A \cap B)=(n(A)+(B))-(n(S)-(x))$

PT : Kenapa kamu memilih operasi 211 himpunan pada irisan dalam menyelesaikan soal tersebut?

JW : (Sambil melihat hasil 211 pekerjaannya), karena dengan operasi himpunan irisan ini cocok untuk kita gunakan dalam menyelesaikan soal ini

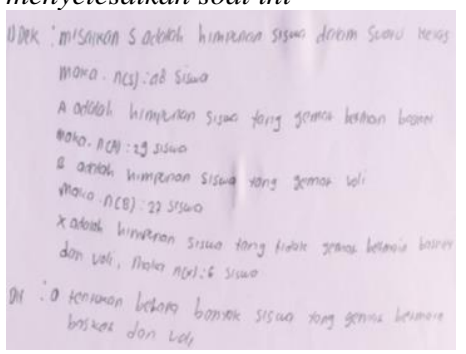

Karena dengan operasi himpunan irisan bisa kita gunakan untuk mencari beberapa banyak siswa yang gemar bermain basket dan voli.

3. Validasi dan Kesimpulan Data Subjek JW

Untuk mengetahui validitas data terhadap konsep dalam pemecahan masalah matematika siswa ditinjau dari persepsi subjek JW dalam indikator pemahaman pada TPM I dengan TPM II maka dilakukan triangulasi waktu. Triangulasi yang dimaksud dapat dilihat pada Tabel 5.

Tabel 5. Validasi Data Subjek JW Pada Indikator Pemahaman

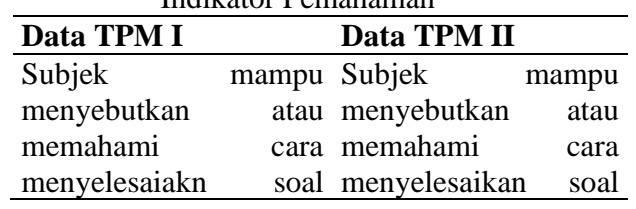


Petrus Gelang, Kristoforus Djawa Djong dan Irmina Veronika Uskono

Anargya: Jurnal Ilmiah Pendidikan Matematika, Vol. 3 No.1, April 2020

\begin{tabular}{|c|c|c|}
\hline Data TPM I & & Data TPM II \\
\hline (JW 109) & & (JW 209) \\
\hline $\begin{array}{l}\text { Subjek } \\
\text { menyebutkan } \\
\text { pengetahuan } \\
\text { digunakan } \\
\text { menyelesaikan } \\
\text { (JW 111) }\end{array}$ & $\begin{array}{r}\text { yang } \\
\text { untuk } \\
\text { soal }\end{array}$ & $\begin{array}{lr}\text { Subjek } & \text { mampu } \\
\text { menyebutkan } & \\
\text { pengetahuan } & \text { yang } \\
\text { digunakan } & \text { untuk } \\
\text { menyelesaikan } & \text { soal } \\
\text { (JW 211) } & \\
\end{array}$ \\
\hline
\end{tabular}

Tabel 5 menunjukkan ada konsistensi subyek JW dalam indikator pemahaman pada TPM I dan TPM II. Oleh karena itu data indikator pemahaman pada TPM I merupakan data yang valid.

C. Paparan Subjek JW Berdasarkan Indikator Evaluasi

1. Deskripsi Hasil TPM I Subjek JW dalam Indikator Evaluasi

Berikut merupakan hasil wawancara subjek JW pada TPM I:

PT : Pengetahuan apa saja yang dapat

112 kamu gunakan untuk menyelesaikan atau menghitung soal tersebut?

JW : Untuk mencari beberapa banyak

112 siswa yang gemar mata pelajaran matematika dan biologi, kita gunakan operasi himpunan irisan.

PT : Kenapa kamu memililih

113 pengetahuan operasi himpunan irisan untuk menghitung berapa banyak siswa yang gemar matapelajaran matematika dan biologi?

JW : Karena untuk mencari beberapa

113 banyak siswa yang gemar mata pelajaran matematika dan biologi kita gunakan operasi himpunan irisan dimana rumusnya $n(A \cap B=(n(A)+n(B)-(n(S)-n(X))$.

PT : Apakah kamu bisa uraikan dengan 114 jelas langkah- langkah penyelesaian dari soal tersebut?

JW : Bisa pak, (sambil menjelaskan

114 langkah-langkah penyelesaian dari soal tersebut)

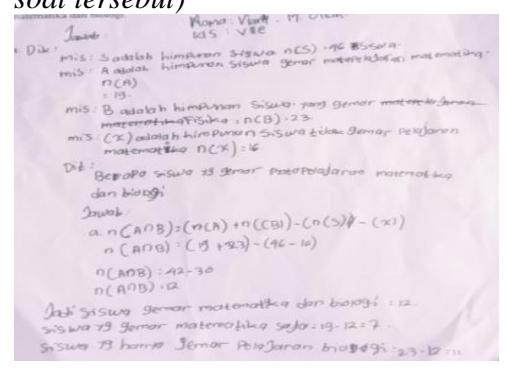

2. Deskripsi Hasil TPM II Subjek JW dalam Indikator Evaluasi
Berikut merupakan hasil wawancara subjek JW pada TPM II:

PT : Pengetahuan apa saja yang dapat

212 kamu gunakan untukmenyelesaikan atau menghitung soal tersebut?

JW : Untuk mencari beberapa banyak

212 siswa yang gemar bermain basket dan voli

PT Kenapa kamu memililih

213 pengetahuan operasi himpunan irisan untuk menghitung berapa banyak siswa yang gemar bermain basket dan voli?

JW : Karena untuk mencari beberapa

213 banyak siswa yang gemar bermain basket dan voli kita gunakan operasi himpunan irisan dimana rumusnya $n(A \cap B=(n(A)+n(B)-(n(S)-n(X))$.

PT : Apakah kamu bisa uraikan dengan

214 jelas langkah-langkah penyelesaian dari soal tersebut?

JW : Bisa pak, (sambil menjelaskan

214 langkah-langkah penyelesaian dari soal tersebut)

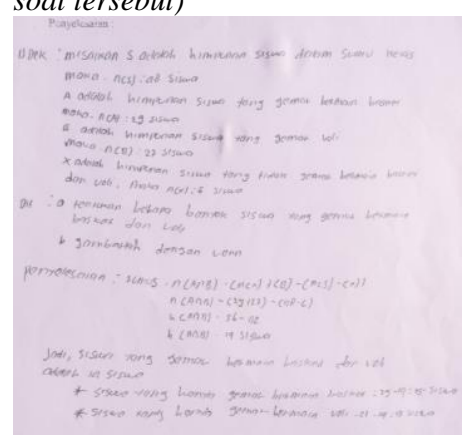

3. Validasi dan Kesimpulan Data Subjek JW

Untuk mengetahui validitas data terhadap konsep dalam pemecahan masalah matematika siswa ditinjau dari persepsi subjek JW dalam indikator evaluasi pada TPM I dengan TPM II maka dilakukan triangulasi waktu yang mencari kesamaan/kesesuaian data wawancara pada TPM I dengan TPM II. Triangulasi yang dimaksud dapat dilihat pada Tabel 6:

Tabel 6. Validasi Data Subjek JW Pada Indikator

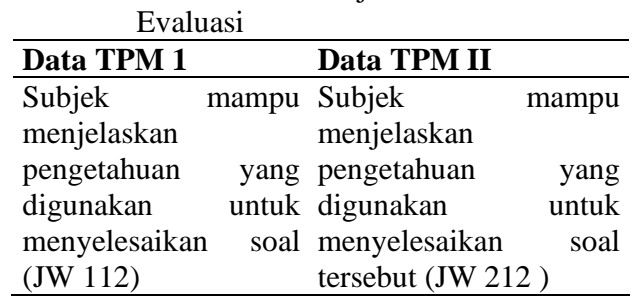




\begin{tabular}{llr}
\hline Data TPM 1 & \multicolumn{2}{l}{ Data TPM II } \\
\hline Subjek mampu & Subjek mampu \\
menjelaskan langkah- & menjelaskan langkah- \\
langkah penyelesaian & langkah penyelesaian \\
dari soal tersebut (JW dari soal tersebut (JW & 214) \\
114) & \\
\hline
\end{tabular}

Tabel 6 menunjukkan ada konsistensi subjek JW dalam indikator evaluasi pada TPM I dan TPM II. Oleh karena itu data indikator evaluasi pada TPM 1 merupakan data yang valid.

D. Paparan Subjek VO Berdasarkan Indikator Penyerapan

1. Deskripsi Hasil TPM I Subjek VO dalam Indikator Penyerapan

Berikut merupakan hasil wawancara subjek VO pada TPM I:

PT : Dapatkah kamu menyebutkan 106 informasi atau hal-hal yang diketahui dari soal tersebut?

VO : Dari soal ini yang diketahui, dalam 106 suatu kelas terdapat 48 siswa. ternyata 29 siswa gemar bermain basket, 27 siswa gemar bermain voli, dan 6 siswa tidak gemar bermain basket dan voli

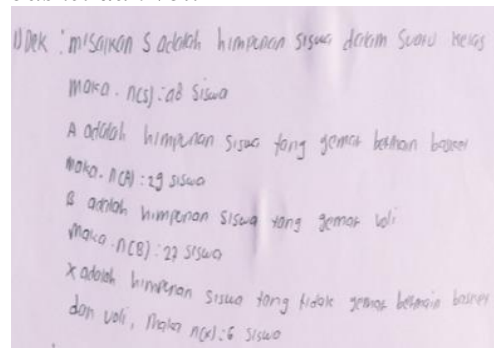

PT : Adik dari soal tersebut, apa sajakah 107 yang ditanyakan?

VO : Yang di tanyakan dalam soal ini 107 adalah yang pertama berapa banyak siswa yang gemar bermain basket dan voli

2. Deskripsi Hasil TPM II Subjek VO dalam Indikator Penyerapan

Berikut merupakan hasil wawancara subjek VO pada TPM II:

PT : Dapatkah kamu menyebutkan hal206 hal yang diketahui dari masalah tersebut?

VO : Dari soal ini yang diketahui 206 adalah dalam suatu kelas terdapat 46 siswa. Mereka diminta untuk memilih dan mempelajari yang mereka gemari. Terdapat 19 siswa gemar mata pelajaran matematika, 23 siswa gemar mata pelajaran fisika, dan 6 siswa tidak gemar mata pelajaran matematika

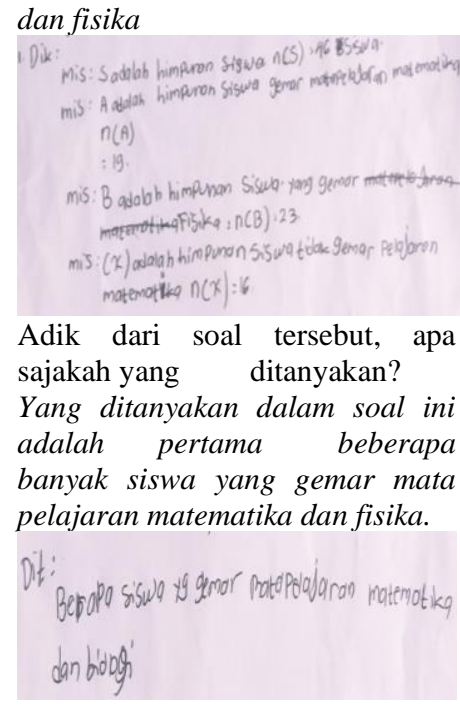

3. Validasi dan Kesimpulan Data Subjek VO

Untuk mengetahui validitas data terhadap konsep dalam pemecahan masalah matematika siswa ditinjau dari presepsi subjek VO dalam indikator penyerapan pada TPM I dan TPM II maka dilakukan triangulasi waktu. Triangulasi yang dimaksud sebagai berikut:

Tabel 7. Validasi Data subjek VO pada Indikator penyerapan

\begin{tabular}{|c|c|}
\hline Data TPM I & Data TPM II \\
\hline $\begin{array}{lr}\text { Subjek } & \text { mampu } \\
\text { menyebutkan informasi } \\
\text { dalam soal tersebut } \\
\text { (VO 106) }\end{array}$ & $\begin{array}{l}\text { Subjek mampu } \\
\text { menyebutkan informasi } \\
\text { dalam soal tersebut } \\
\text { (VO 206) }\end{array}$ \\
\hline $\begin{array}{lr}\text { Subjek mampu } \\
\text { menyebutkan apa yang } \\
\text { ditanyakan dari soal } \\
\text { (VO 107) }\end{array}$ & $\begin{array}{l}\text { Subjek mampu } \\
\text { menyebutkan apa yang } \\
\text { ditanyakan dari soal } \\
\text { (VO 207) }\end{array}$ \\
\hline
\end{tabular}

Tabel 7 menunjukkan ada konsistensi subyek VO dalam indikator penyerapan pada TPM I dan TPM II. Oleh karena data itu indikator penyerapan pada TPM 1 merupakan data yang valid.

E. Paparan Subjek VO Berdasarkan Indikator Pemahaman

1. Deskripsi Hasil TPM I Subjek VO dalam Indikator Pemahaman

Berikut merupakan hasil wawancara subjek VO pada TPM I:

PT : Dari soal tersebut bagaimana cara

109 penyelesaiannya?

VO : Begini pak, (sambil melihat lembar

109 penyelesaian 


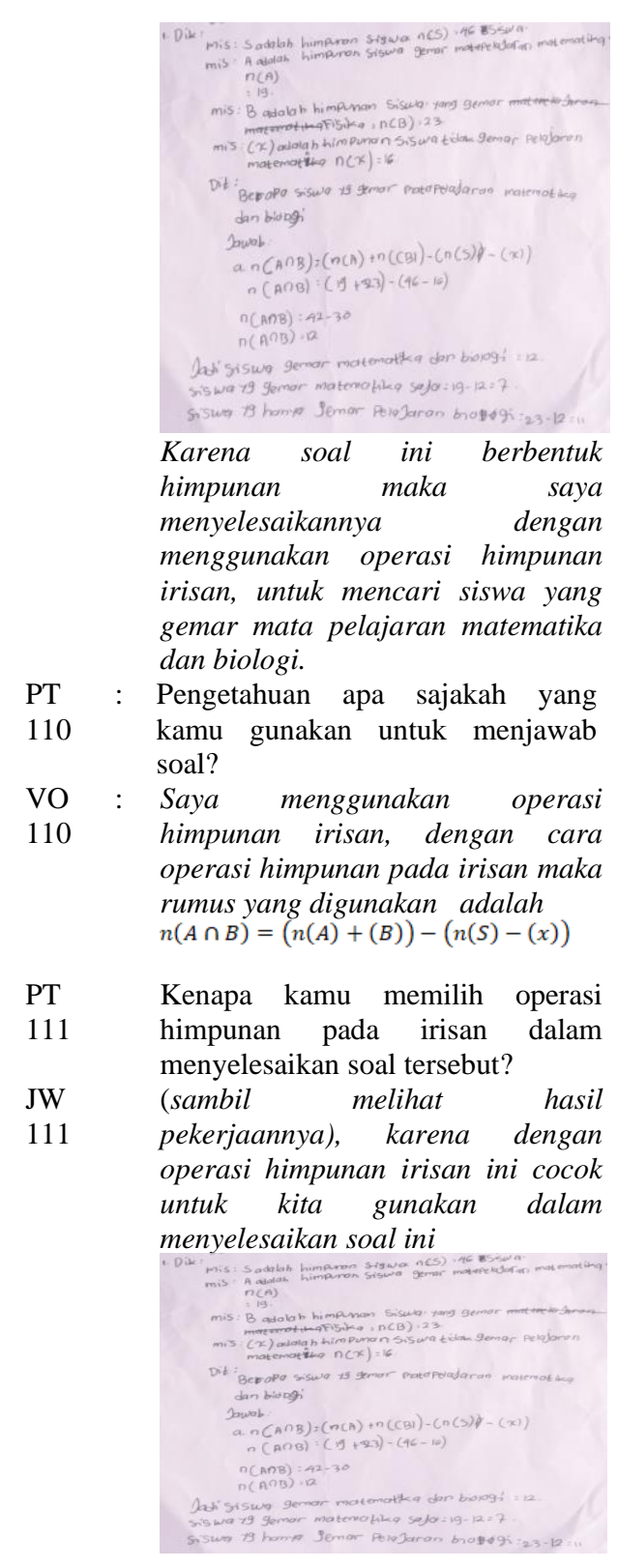

2. Deskripsi Hasil TPM II Subjek VO dalam Indikator Pemahaman

Berikut merupakan hasil wawancara subjek VO pada TPM II:

PT : Dari soal tersebut bagaimana cara

209 penyelesaiannya?

VO : Begini pak, (sambil melihat lembar 209 penyelesaian)

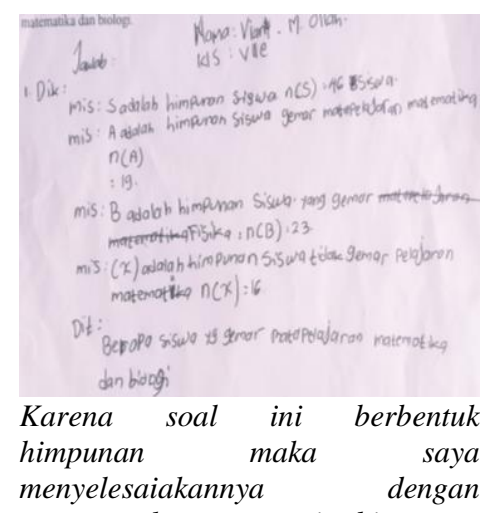

menggunakan operasi himpunan irisan, untuk mencari siswa yang gemar mata pelajaran matematika dan biologi

PT : Pengetahuan apa yang dapat kamu

210 gunakan untuk menyelesaikan soal tersebut?

VO : Saya disini menggunakan

210 pengetahuan operasi himpunan

PT : Mengapa kamu memilih

211 pengetahuan operasi himpunan untuk menyelesaikan soal tersebut?

VO : Disini sesuai dengan yang sudah

211 diketahui bahawa $(S)=46$ siswa, $(A)=19$ siswa, $(B)=23$ siswa, dan $(C)=16$ siswa dan di tanyakan adalah beberapa banyak siswa yang gemar mata pelajaran matematika dan biologi.Maka saya menggunakan operasi himpunan pada irisan untuk menghitungnya

3. Validasi dan Kesimpulan Data Subjek VO

Untuk mengetahui validitas data terhadap konsep dalam pemecahan masalah matematika siswa ditinjau dari presepsi subjek VO dalam indikator pemahaman pada TPM I dan TPM II maka dilakukan triangulasi waktu. Triangulasi yang dimaksud dapat dilihat pada Tabel 8.

Tabel 8. Validasi Data Subjek VO pada Indikator Pemahaman

\begin{tabular}{lrlr}
\hline \multicolumn{3}{c}{ Data TPM II } \\
\hline Subjek TPM I & mampu & Subjek & mampu \\
menyebutkan & atau & menyebutkan & atau \\
memahami & cara & memahami & cara \\
menyelesaikan & soal & menyelesaikan & soal \\
(VO 109) & & (VO 209) & \\
\hline Subjek & mampu & Subjek menyebutkan \\
menyebutkan & operasi & operasi himpunan irisan \\
himpunan & irisan & untuk menyelesaikan \\
uantuk menyelesaikan & soal (VO 211) \\
soal (VO 111) & & \\
\hline
\end{tabular}

Tabel 8 menunjukkan ada konsistensi subjek VO dalam indikator pemahaman pada TPM I dan TPM II. Oleh karena itu data indikator 
pemahaman pada TPM I VO merupakan data yang valid.

F. Paparan Subjek VO Berdasarkan Indikator Evaluasi

1. Deskripsi Hasil TPM I Subjek VO dalam Indikator Evaluasi

Berikut merupakan hasil wawancara subjek VO pada TPM I:

PT : Kenapa kamu memililih pengetahuan

113 operasi himpunan irisan untuk menghitung berapa banyak siswa yang gemar matapelajaran matematika dan biologi?

VO : Karena untuk mencari beberapa banyak

113 siswa yang gemar mata pelajaran matematika dan biologi, kita gunakan operasi himpunan irisan dimana rumusnya

$n(A \cap B=(n(A)+n(B)-(n(S)-n(X))$.

PT : Apakah kamu bisa uraikan dengan jelas

114 langkah-langkah penyelesaian dari soal tersebut?

VO : Bisa pak, (sambil menjelaskan langkah-

114 langkah penyelesaian dari soal tersebut)

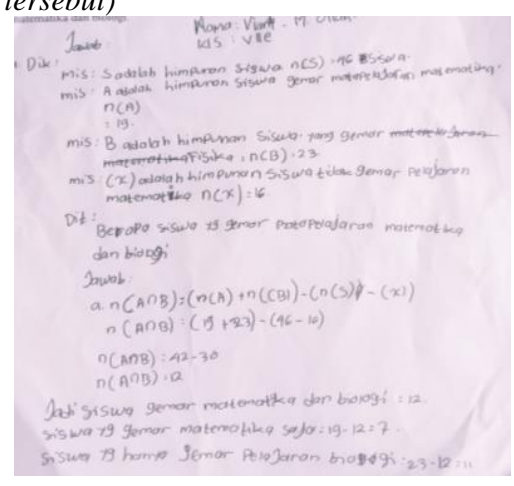

2. Deskripsi Hasil TPM II Subjek VO dalam Indikator Evaluasi

Berikut merupakan hasil wawancara subjek VO pada TPM II:

PT : Kenapa kamu memililih

213 pengetahuan operasi himpunan irisan untuk menghitung berapa banyak siswa yang gemar bermain basket dan voli?

VO : Karena untuk mencari beberapa

213 banyak siswa yang gemar bermain basket dan voli kita gunakan operasi himpunan irisan dimana rumusnya $n(A \cap B=(n(A)+n(B)-(n(S)-n(X))$.

PT Apakah kamu bisa uraikan dengan 214 jelas langkah-langkah penyelesaian dari soal tersebut?

VO Bisa pak, (sambil menjelaskan

214 langkah-langkah penyelesaian dari

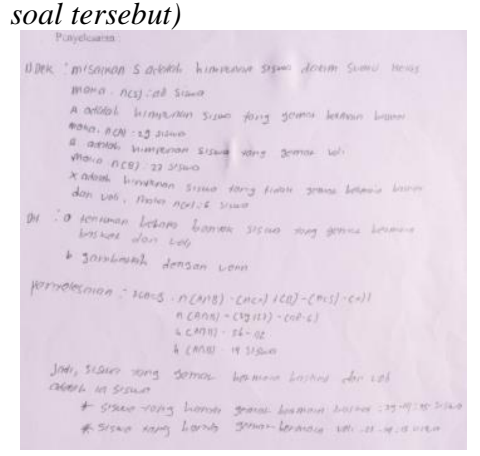

3. Validasi dan Kesimpulan Data Subjek VO

Untuk menguji validitas data terhadap konsep dalam pemecahan masalah matematika siswa ditinjau dari presepsi subjek VO dalam indikator evaluasi pada TPM I dan TPM II maka dilakukan triangulasi waktu yaitu mencari kesamaan/kesusaian data wawancara pada TPM I dengan TPM II. Triangulasi yang dimaksud dapat dilihat pada Tabel 9.

Tabel 9. Validasi data Subjek VO Pada Indikator Evaluasi

\begin{tabular}{|c|c|}
\hline Data TPM I & Data TPM II \\
\hline $\begin{array}{lr}\text { Subjek } & \text { mampu } \\
\text { menjelaskan } & \\
\text { pengetahuan } & \text { yang } \\
\text { digunakan } & \text { untuk } \\
\text { menyelesaikan } & \text { soal } \\
\text { tersebut (VO 113) } & \\
\end{array}$ & $\begin{array}{lr}\text { Subjek } & \text { mampu } \\
\text { menjelaskan } & \\
\text { pengetahuan } & \text { yang } \\
\text { digunakan } & \text { untuk } \\
\text { menyelesaikan } & \text { soal } \\
\text { tersebut (VO 213) } & \\
\end{array}$ \\
\hline $\begin{array}{lr}\text { Subjek } & \text { mampu } \\
\text { menjelaskan } & \text { langkah- } \\
\text { langkah penyelesaian } \\
\text { dari soal } \\
(\text { VO114) }\end{array}$ & $\begin{array}{lr}\text { Subjek mampu } & \text { menjelaskan langkah- } \\
\text { langkah penyelesaian } \\
\text { dari soal tersebut } \\
(\mathrm{VO} 214)\end{array}$ \\
\hline
\end{tabular}

Tabel 9 menunjukkan ada konsistensi subjek VO dalam indikator evaluasi pada TPM I dan TPM II. Oleh karena itu data indikator evaluasi pada TPM 1 merupakan data yang valid.

Dalam pelaksanaan penelitian ini ditemukan bahwa terdapat subjek yang memiliki sifat agak malu dan merasa cemas ketika akan diwawancara. Ini dikarenakan subjek berpikir bahwa terdapat kekeliruan dalam menyelesaikan soal TPM yang diberikan dan subjek berusaha untuk mengingat kembali hasil pekerjaannya. Hal ini sejalan dengan pendapat Toha (Arifin, 2017) bahwa persepsi dipengaruhi oleh faktor internal dan eksternal. Namun, peneliti berupaya dengan baik sehingga perhatian (fokus) siswa yang menjadi subjek penelitian tertuju kembali untuk menyelesaikan soal TPM dan juga ketika diwawancarai.

Berdasarkan hasil penelitian yang telah diuraikan tersebut, dapat dikatakan bahwa: subjek 
JW pada aspek penyerapan mampu menceritakan soal serta dapat menentukan hal-hal yang diketahui dan ditanyakan pada soal dan mampu menyebutkan. Pada aspek pemahaman, subjek mampu menyebutkan atau memahami cara penyelesaian soal dan subjek mampu menyebutkan operasi himpunan irisan untuk menyelesaikan soal. Pada aspek evaluasi / penilaian subjek JW mampu menjelaskan pengetahuan yang digunakan untuk menyelesaikan soal serta menjelaskan langkahlangkah penyelesaian soal. Dengan demikian dapat dikatakan bahwa subjek JW memenuhi indikator persepsi yang dikemukakan oleh Bimo Walgito (Akbar, 2015).

Subjek VO pada aspek penyerapan mampu menyebutkan informasi dalam soal dan mampu menyebutkan apa yang ditanyakan dari soal. Pada aspek pemahaman mampu menyebutkan cara menyelesaikan soal dan mampu menyebutkan operasi himpunan irisan untuk menyelesaikan soal. Pada aspek evaluasi / penilaian mampu menjelaskan pengetahuan yang digunakan untuk menyelesaikan soal dan menjelaskan langkah- langkah penyelesaian soal. Dengan demikian dapat dikatakan bahwa subjek VO memenuhi indikator persepsi yang dikemukakan oleh Bimo Walgito (Akbar, 2015).

\section{SIMPULAN}

Berdasarkan hasil penelitian dan pembahasan yang telah diuraikan, dapat disimpulkan bahwa kedua subyek dengan tingkat kemampuan tinggi mampu memenuhi ketiga indikator persepsi.

\section{DAFTAR PUSTAKA}

Akbar, Rofiq Faudi. Analisis Persepsi Pelajar Tingkat menengah Pada Sekolah Tinggi Agama Islam Negeri Kudus. Edukasia: Jurnal Penelitian Pendidikan Islam, 10 (1): 180-209.

Arifin, Hadi Suprapto; Ikhsan Fuady dan Engkus Kuswarno. 2017. Analisis Faktor Yang Mempengaruhi Persepsi Mahasiswa UNTIRTA Terhadap Keberadaan Perda Syariah Di Kota Serang. Jurnal Penelitian Komunikasi dan Opini Publik, 21 (1): 88101.

Chotimah. 2014. Pengaruh Model Pembelajaran Generatif (MPG) Terhadap Kemampuan Pemecahan Masalah dan Disposisi Matematis Siswa di Kelas X pada SMA Negeri 8 Palembang (Skripsi). Palembang : Universitas PGRI Palembang.
Mulyono. 2010. Pendidikan bagi Anak Berkesulitan Belajar. Jakarta: PT Rineka Cipto.

Ratnasari. 2014. Pengaruh Model Pembelajaran Generatif terhadap Kemampuan Pemecahanan Masalah Matematika Siswa. Jakarta: tidak dipublikasikan.

Setiadi, N. J. 2015. Perspektif kontemporer pada motif, tujuan, dan keinginan konsumen. Perilaku konsumen, Prenada Media Group.

Tarmiji, Muhammad N Basyah dan Muhammad Yunus. 2016. Persepsi Siswa terhadap Kesiapan Guru Dalam Proses Pembelajaran (Studi Pada SMP Negeri 18 Banda Aceh). Jurnal Ilmiah Mahasiswa Pendidikan Kewarganegaraan Unsyiah, 1 (1) : 41-48. 